\title{
The use of Crambe abyssinica seeds as adsorbent in the removal of metals from waters
}

\author{
Affonso C. Gonçalves Jr. ${ }^{1}$, Fernanda Rubio', Ana P. Meneghel', \\ Gustavo F. Coelho', Douglas C. Dragunski ${ }^{2} \&$ Leonardo Strey ${ }^{1}$
}

\begin{abstract}
RESUMO
This study aimed to evaluate the efficacy of crambe seeds (Crambe abyssinica Hochst) as adsorbent material in the removal of the toxic metals cadmium, lead and chromium from contaminated solutions. The byproduct was obtained from oil extraction of crambe seeds in a Soxhlet system. In kinetic tests, the adsorbent masses had varied in solutions containing the metals under $\mathrm{pH} 5.0$ and 7.0. Metal concentrations were determined by flame atomic absorption spectrometry (FAAS). According to optimal conditions found, the adsorption assays were performed for obtaining the isotherms of each metal, which were linearized in agreement with the mathematical models of Langmuir and Freundlich. According to the obtained results, the adsorbent was effective in removing the assessed metals in aqueous solutions, being feasible its employment as an alternative material for the adsorption of metals, besides being a byproduct, which has undergone no prior treatment.
\end{abstract}

Palavras-chave: biosorption, remediation of waters, sustainability

\section{Uso de sementes de Crambe abyssinica como adsorvente na remoção de metais de águas}

\begin{abstract}
Objetivou-se, neste trabalho, avaliar a eficácia do uso das sementes de crambe (Crambe abyssinica Hochst) como material adsorvente na remoção dos metais pesados tóxicos cádmio, chumbo e cromo de soluções contaminadas. Obteve-se a torta a partir da extração do óleo das sementes de crambe em sistema tipo Soxhlet. Nos testes cinéticos as massas do adsorvente variaram em soluções contendo os metais em condições de $\mathrm{pH} 5.0$ e 7.0. As concentrações dos metais foram determinadas por espectrometria de absorção atômica modalidade chama (EAA/chama). De acordo com as condições ótimas encontradas ensaios de adsorção foram realizados para a construção das isotermas de cada metal as quais, por sua vez, foram linearizadas conforme os modelos matemáticos de Langmuir e Freundlich. Com base nos resultados obtidos concluiuse que o adsorvente foi eficaz na remoção dos metais estudados em soluções aquosas, sendo viável sua utilização como material alternativo para adsorção dos metais pesados, além de se tratar de um coproduto que não sofreu tratamento prévio algum.
\end{abstract}

Key words: biossorção, remediação de águas, sustentabilidade

UNIOESTE, Rua Pernambuco 1777, CEP 85960-000, Marechal Cândido Rondon, PR. Fone: (45) 3284-7924. E-mail: affonso133@hotmail.com; fernandarubiofoz@hotmail.com; mel_meneghel@hotmail.com; gfc faramir@hotmail.com; leonardostrey@yahoo.com.br 2 UNIPAR, Praça Mascarenhas de Moraes, s/n, CEP 87502-210, Umuarama, PR. Fone: (44) 3621-2828. E-mail: dcdragrunski@unipar.br 


\section{INTRODUCTION}

The increased environmental pollution caused by metals is a matter of great concern due to the toxic effects that they may cause to human beings, animals and environment (Bayramoglu $\&$ Arica, 2011), and the main sources of contamination are the industrial effluents, mining, and agricultural activities (Aguiar et al., 2002).

Among the toxic metals, the chromium $(\mathrm{Cr})$ can be considered vital, since it is used in the biological metabolism, but is carcinogen in its hexavalent form, while $\mathrm{Pb}$ and $\mathrm{Cd}$ are not essential, being toxic even at trace levels (Gonçalves Jr. et al., 2009).

These metals are a group of pollutants that requires special treatment, because they are not biologically or chemically degraded naturally, on the other hand, they are cumulative and may become even more harmful when reacting with components of the soil and sediments found in polluted effluents (Reedy et al., 2010). In this way, water resources are protected by environmental laws, where the Brazilian Environmental National Council (CONAMA), through the Resolution number 357 , from March $17^{\text {th }}, 2005$, establishes maximum permitted values for each metal in water bodies, being $0.01 \mathrm{mg} \mathrm{L}^{-1}$ for $\mathrm{Cd}, 0.033 \mathrm{mg} \mathrm{L}^{-1}$ for $\mathrm{Pb}$, and $0.05 \mathrm{mg} \mathrm{L}^{-1}$ for $\mathrm{Cr}$ (Brasil, 2005). The Ordinance number 518 of the Ministry of Health, which establishes the procedures and responsibilities relative to control and surveillance of water quality for human consumption and its potability standards stipulates even lower values for both, $\mathrm{Pb}\left(0.01 \mathrm{mg} \mathrm{L}^{-1}\right)$ and $\mathrm{Cd}\left(0.005 \mathrm{mg} \mathrm{L}^{-1}\right)$ (Brasil, 2004).

One of the remediation alternatives for natural resources contaminated with metals is the adsorption process, because it regulates the mobility and bioavailability of pollutants in solution (Sousa et al., 2007). The adsorption process can be quantitatively assessed by isotherms that express the relationship between the amount of the material that is sorbed per unit of adsorbent mass and the concentration of the metal in solution at equilibrium (Salehizadeh \& Shojaosadati, 2003).

The adsorption of toxic metals is more promising when using natural adsorbents, such as wastes from industry and agriculture. These adsorbents are excellent alternatives to chemical remediation, due to its adsorption capacity, low cost, and high availability (Demirbas, 2008).

Some recent studies have proved the feasibility of these materials as adsorbents in the removal of metals. Applications of sugarcane bagasse in the biosorption of copper (Santos et al., 2010); rice husk used in the adsorption of copper, aluminum, nickel and zinc (Mimura et al., 2010); dry biomass of Eichorniacrassipes used in the removal of cadmium, lead and chromium (Gonçalves Jr. et al., 2009), are some examples of biosorbents.

The crambe (Crambe abyssinica Hochst), a plant belonging to the cruciferous family (Pitol, 2010), has shown efficient results when used in adsorption assays with dye (Oliveira et al., 2009), but until the moment, there is no information about this material as biosorbent for metals.

This crop has attracted great interest due to its total oil content between 36 and $38 \%$, and 55 and $60 \%$ of erucic oil. The crambe oil and its derivatives are present in a wide range of applications, including lubricants, additive production, polymers, base for paints and coatings, besides biodiesel production (Pitol et al., 2010).

The byproduct is obtained from the oil extraction of crambe seeds. However the information about this material is scarce, due this culture is not well known, and without an established supply chain in Brazil (Souza et al., 2009). In this way, is extremely important to assess the feasibility of this material for defining its potential uses.

Considering the advantages associated to the crambe crop and the need for finding new natural adsorbents, the present work aimed to study the reuse of the byproduct of crambe seeds on the adsorption of the metals $\mathrm{Cd}, \mathrm{Pb}$ and $\mathrm{Cr}$ in contaminated waters.

\section{Material And Methods}

Crambe seeds (Crambe abyssinica Hochst) were obtained in the Brazilian cerrado region, Jataí city, Goiás State. The seeds were ground and oven-dried at $60^{\circ} \mathrm{C}$ for $36 \mathrm{~h}$. Afterwards, the oil was extracted from the seeds through the Soxhlet system (IUPAC, 1988) thus obtaining the byproduct, which was oven-dried again at $60{ }^{\circ} \mathrm{C}$ for $24 \mathrm{~h}$ for complete evaporation of n-hexane used in oil extraction.

A sample of crambe byproduct was subjected to nitroperchloric digestion (AOAC, 2005) to determine the concentrations of $\mathrm{Cd}, \mathrm{Pb}$ and $\mathrm{Cr}$ by flame atomic absorption spectrometry (FAAS) (Welz \& Sperling, 1999).

Aqueous solutions $(1000 \mathrm{~mL})$ fortified with $\mathrm{Cd}, \mathrm{Pb}$ and $\mathrm{Cr}$ were prepared and obtained from an aliquot of stock standard solution $\left(100 \mu \mathrm{g} \mathrm{mL}^{-1}\right)$.

For the verification of the ideal adsorption conditions, mass tests were performed, using increasing amounts of adsorbent material $(0,150,300,450,600,750$ and $900 \mathrm{mg})$ under two $\mathrm{pH}$ conditions (5.0 and 7.0), adjusted and buffered with $\mathrm{HCl}$ or $\mathrm{NaOH}$ solutions at concentrations of $0.100 \mathrm{~mol} \mathrm{~L}^{-1}$.

The masses were added to erlenmeyer flasks $(125 \mathrm{~mL})$ which received fixed volume of $50 \mathrm{~mL}$ of the aqueous solution fortified with metals studied at the following concentrations $\mathrm{Cd}$ $0.05, \mathrm{~Pb} 0.10$ and $\mathrm{Cr} 0.50 \mu \mathrm{g} \mathrm{mL}^{-1}$. The selected concentration of each metal was exactly 10 times the maximum allowed, according to the Ordinance $n^{\circ} 518$ of the Ministry of Health (Brasil, 2004).

Erlenmeyers were agitated for $90 \mathrm{~min}$, with constant temperature and agitation $\left(25^{\circ} \mathrm{C}\right.$ and $\left.200 \mathrm{rpm}\right)$ in a thermostatized water bath. Afterwards, $10 \mathrm{~mL}$ aliquots were taken from this solution and centrifuged at $3000 \mathrm{rpm}$ for $5 \mathrm{~min}$ to separate the adsorbent from the aqueous solution for later determining concentrations of $\mathrm{Cd}, \mathrm{Pb}$ e $\mathrm{Cr}$ in the solution by FAAS (Welz \& Sperling, 1999).

The point of zero charge $\left(\mathrm{pH}_{\mathrm{PZC}}\right)$ is defined as the $\mathrm{pH}$ in which the solid surface has neutral charge (Mimura et al., 2010). The procedure to determine the $\mathrm{pH}_{\mathrm{PZC}}$ consists of making a mixture of $50 \mathrm{mg}$ of the adsorbent in $50 \mathrm{~mL}$ of $\mathrm{KCl}$ aqueous solution at 0.05 and $0.5 \mathrm{~mol} \mathrm{~L}^{-1}$ in values of initial $\mathrm{pH}$ ranging from 2.0 to 10.0 , which were buffered with solutions of $\mathrm{HCl}$ and $\mathrm{NaOH}\left(0.1 \mathrm{~mol} \mathrm{~L}^{-1}\right)$. After $24 \mathrm{~h}$ of agitation, the final $\mathrm{pH}$ values were obtained resulting in a graph of $\mathrm{pH}$ variation (initial vs. 
final) where for each $\mathrm{KCl}$ concentration, the range that remained constant of $\mathrm{pH}$ variation corresponded to the $\mathrm{pH}_{\mathrm{PZC}}$.

In order to obtain the adsorption isotherms, it was performed assays based on the best results obtained in the tests of mass and $\mathrm{pH}$ previously performed. Therefore, $300 \mathrm{mg}$ of the byproduct of crambe seeds were added in erlenmeyers $(125 \mathrm{~mL})$ with the solution fortified in different concentrations of toxic metals.

The aqueous solution with metals was prepared at the following concentrations: $\mathrm{Cd} 0.20, \mathrm{~Pb} 0.40$ and $\mathrm{Cr} 2.0 \mu \mathrm{g} \mathrm{mL}-$ ', from the stock solution of $100 \mu \mathrm{g} \mathrm{mL}^{-1}$, buffered at $\mathrm{pH} 5.0$, and the values of these concentrations chosen corresponded to 40 times the maximum allowed by the Ordinance $\mathrm{n}^{\circ} 518$ of the Ministry of Health (Brasil, 2005).

Into volumetric flasks $(50 \mathrm{~mL})$ were added increasing volumes of the fortified solution $(5.0,10.0,15.0,20.0,25.0$, $30.0,35.0,40.0,45.0 \mathrm{~mL}$ ), and the final volume was completed to $50 \mathrm{~mL}$ with distilled and deionized water. In this way, the initial concentrations of the metals were increasing according to the volume used in the fortified aqueous solution (Table 1).

Table 1. Concentration of the metals $\mathrm{Cd}, \mathrm{Pb}$ and $\mathrm{Cr}$ at equilibrium in the solution $\left(\mathrm{C}_{\mathrm{eq}}\right)$ in the mass test at $\mathrm{pH} 5.0$ and 7.0

\begin{tabular}{|c|c|c|c|}
\hline \multirow{2}{*}{$\begin{array}{l}\text { Mass crambe } \\
(\mathrm{mg})\end{array}$} & Cd & $\overline{\mathrm{Pb}}$ & $\mathrm{Cr}$ \\
\hline & \multicolumn{3}{|c|}{$\left(\mathrm{mg} \mathrm{L}^{1}\right)$} \\
\hline \multicolumn{4}{|c|}{ pH 5.0} \\
\hline 0 & 0.050 & 0.100 & 0.500 \\
\hline 0.150 & 0.011 & 0.071 & 0.379 \\
\hline 0.300 & 0.009 & 0.076 & 0.359 \\
\hline 0.450 & 0.010 & 0.074 & 0.406 \\
\hline 0.600 & 0.010 & 0.078 & 0.389 \\
\hline 0.750 & 0.013 & 0.081 & 0.396 \\
\hline 0.900 & 0.011 & 0.077 & 0.404 \\
\hline \multicolumn{4}{|c|}{$\mathrm{pH} 7.0$} \\
\hline 0 & 0.050 & 0.100 & 0.500 \\
\hline 0.150 & 0.015 & 0.100 & 0.401 \\
\hline 0.300 & 0.011 & 0.075 & 0.376 \\
\hline 0.450 & 0.011 & 0.076 & 0.387 \\
\hline 0.600 & 0.011 & 0.078 & 0.396 \\
\hline 0.750 & 0.012 & 0.076 & 0.363 \\
\hline 0.900 & 0.013 & 0.079 & 0.408 \\
\hline
\end{tabular}

The volumes of each volumetric flasks were individually transferred to erlenmeyers with $125 \mathrm{~mL}$ containing the masses of the adsorbent $(300 \mathrm{mg})$. The samples were stirred at 200 $\mathrm{rpm}$ in a thermostatized water bath at $25^{\circ} \mathrm{C}$, for $90 \mathrm{~min}$ then, aliquots of this solution were taken to centrifugation at $3000 \mathrm{rpm}$ for $5 \mathrm{~min}$, aiming to separate the adsorbent from the aqueous solution, and then it was determined the content of metals in the solutions by FAAS (Welz \& Sperling, 1999).

The adsorbed amount of each metal was determined by using the Eq. 1:

$$
\mathrm{Q}_{\mathrm{eq}}=\frac{\left(\mathrm{C}_{0}-\mathrm{C}_{\mathrm{eq}}\right)}{\mathrm{m}} \mathrm{V}
$$

where:

$\mathrm{Q}_{\mathrm{eq}}$ - amount of adsorbed material, $\mathrm{mg} \mathrm{g}^{-1}$

$\mathrm{m}$ - mass of the used adsorbent, $\mathrm{g}$

$\mathrm{C}_{0} \quad$ - initial concentration of the metal in the solution, $\mathrm{mg} \mathrm{L}^{-1}$
$\operatorname{mg~L} \mathrm{L}^{-1}$

$\mathrm{C}_{\mathrm{eq}}$ - equilibrium concentration of the metal in the solution,

V - volume of solution used, L

The removal percentage $(\% \mathrm{R})$ of the metal solution was calculated according to the Eq. 2 :

$$
\% \mathrm{R}=100\left(\frac{\mathrm{C}_{\mathrm{eq}}}{\mathrm{C}} 100\right)
$$

where:

$\% \mathrm{R}$ - removal percentage of the metal solution by the byproduct of crambe seeds

$\mathrm{C}_{\mathrm{eq}}$ - equilibrium concentration of the metal in the solution, $\mathrm{mg} \mathrm{L} \mathrm{C}^{-1}$

$\mathrm{C}_{0} \quad$ - initial concentration of the metal in the solution, $\mathrm{mg} \mathrm{L}^{-1}$

For the linearization of the adsorption isotherms, the mathematical models of Langmuir (Eq. 3) and Freundlich (Eq. 4) were used:

$$
\frac{\mathrm{C}_{\mathrm{eq}}}{\mathrm{Q}_{\mathrm{eq}}}=\frac{1}{\mathrm{q}_{\mathrm{m}} \mathrm{b}}+\frac{\mathrm{C}_{\mathrm{eq}}}{\mathrm{q}_{\mathrm{m}}}
$$

where:

$\mathrm{C}_{\text {eq }}$ - equilibrium concentration of the metal in the solution, $\mathrm{mg} \mathrm{L}{ }^{-1}$

$\mathrm{Q}_{\mathrm{eq}}$ - adsorbed amount at equilibrium per mass unit of the adsorbent, $\mathrm{mg} \mathrm{g}^{-1}$

$\mathrm{q}_{\mathrm{m}} \quad$ - maximum adsorption capacity, $\mathrm{mg} \mathrm{g}^{-1}$

$\mathrm{b}$ - parameter of the Langmuir isotherm related to the adsorbent-adsorbate interactions

$$
\log \mathrm{Q}_{\mathrm{eq}}=\log \mathrm{K}_{\mathrm{f}}+\left(\frac{1}{\mathrm{n}}\right) \log \mathrm{C}_{\mathrm{eq}}
$$

in which:

$\mathrm{C}_{\text {eq }}$ - equilibrium concentration of the metal in the solution, $\mathrm{mg} \mathrm{L}^{-1}$

$\mathrm{Q}_{\mathrm{eq}}$ - adsorbed amount at equilibrium per mass unit of the adsorbent, $\mathrm{mg} \mathrm{g}^{-1}$

$\mathrm{K}_{f}$ and nare the two parameters of Freundlich, and $\mathrm{K}_{f}$ is related with the adsorption capacity and $\mathrm{n}$ is related to heterogeneity of the solid.

\section{RESUlts AND Discussion}

The results of the determination of the toxic metals in the crambe byproduct were $1.00 \mu \mathrm{g} \mathrm{Cd} \mathrm{g}^{-1}, 2.37 \mu \mathrm{g} \mathrm{Pb} \mathrm{g}^{-1}$ and 0.77

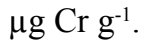

The plants absorb directly the toxic metals from the soil or via application of pesticides and fertilizers, which have in their composition, beyond desirable elements, also metals such as $\mathrm{Cd}, \mathrm{Pb}$ and $\mathrm{Cr}$ (Gonçalves Jr. \& Pessoa, 2002). These elements may come from indiscriminate disposal of industrial waste as fertilizers containing micronutrients, which are a great concern, since these elements persist in the soil, becoming a source of 
metal contamination to the environment (Gonçalves Jr. et al., 2000; 2011).

In this way, the presence of these elements in the studied adsorbent material can be justified, because it is a plant cultivated in an agricultural area where the soil is often subjected to the application of these substances.

The adsorption of positive charges in any adsorbent will be enhanced for operations at $\mathrm{pH}$ values higher than the $\mathrm{pH}_{\mathrm{PZC}}$, while the adsorption of negative charges will be favored for operations below the $\mathrm{pH}_{\mathrm{PZC}}$ (Abia \& Usuquo, 2006).

The results obtained in the $\mathrm{KCl}$ solutions used indicated that for the crambe, the point of zero charge is around 5.5 (Figure 1).

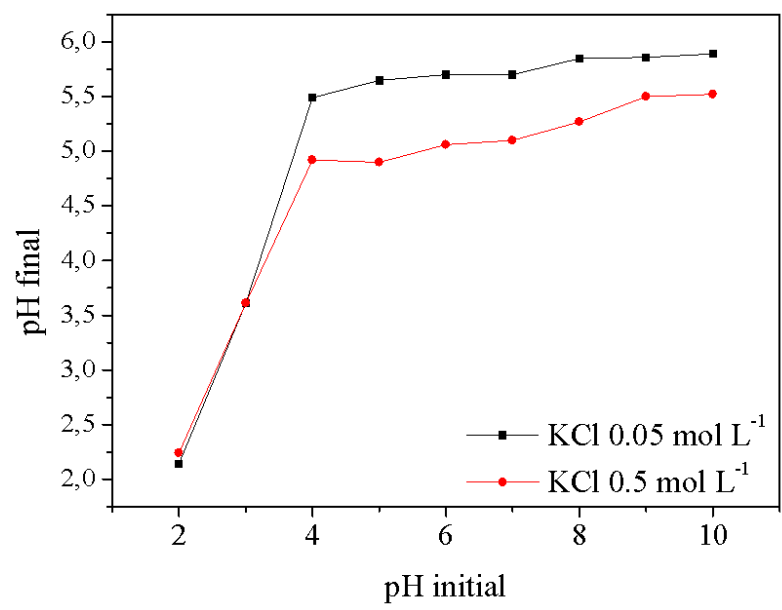

Figure 1. Values of initial and final $\mathrm{pH}$ in the experiment of $\mathrm{pH}_{\mathrm{PZC}}$

It is known that the adsorption of metal species present in solution in the cationic form is favored at $\mathrm{pH}$ in which the negative species predominate on the biosorbent surface. Nevertheless, in the present study, solution at $\mathrm{pH} 5.0$ was used for the adsorption tests, because the metals have their mobility reduced with increasing $\mathrm{pH}$, due to the precipitation of insoluble forms (Kabata-Pendias \& Pendias, 1987), which was corroborated by Sud et al. (2008) who reported that for Cd and $\mathrm{Pb}$, the optimum $\mathrm{pH}$ values for adsorption, using agricultural waste, were those of acidic character.

However, $\mathrm{pH}$ values much lower than found in the $\mathrm{pH}_{\mathrm{PZC}}$ test ( $\mathrm{pH}$ 5.0) are not recommended because the ionizable surface groups can be protonated, since the $\mathrm{H}^{+}$compete with metals in the active sites of the biomass, thus generating a net positive charge that can cause the repulsion between the surface and the cations in solution, leading to a low adsorption of the same (Mimura et al., 2010).

The use of solutions with $\mathrm{pH}$ below those found in the $\mathrm{pH}_{\mathrm{PZC}}$ for adsorption tests was verified in a study using rice husk to adsorb metallic ions, where the $\mathrm{pH}_{\mathrm{PZC}}$ was 7.0; and Mimura et al. (2010) opted to use $\mathrm{pH}$ around 4.0 and 5.0, because according to these authors in this range, although the adsorbent surface presented the great part of its surface groups protonated, there is no excess of positive charge, favoring both processes, the ion exchange and the electrostatic interaction.

According to Table 1 and 2, it was verified that to reach a similar efficiency as obtained under $\mathrm{pH} 5.0$, the solution in $\mathrm{pH}$ 7.0 demanded a greater amount of adsorbent material, with a
Table 2. Parameters of the equilibrium isotherm models of the Langmuir and Freundlich for the adsorption process of the metals by the crambe by product

\begin{tabular}{|c|c|c|c|c|c|c|}
\hline \multirow[b]{2}{*}{ Metal } & \multicolumn{3}{|c|}{ Langmuir constants } & \multicolumn{3}{|c|}{ Freundlichconstants } \\
\hline & $\underset{\left(m g ~ g^{-1}\right)}{q_{m}}$ & $\begin{array}{c}\mathbf{b} \\
\left(\mathrm{L} \mathrm{mg}^{-1}\right)\end{array}$ & $\mathrm{R}^{2}$ & $\begin{array}{c}\mathrm{K}_{f} \\
\left(\mathrm{mg} \mathrm{g}^{-1}\right)\end{array}$ & $\mathrm{n}$ & $\mathbf{R}^{2}$ \\
\hline $\mathrm{Cd}$ & 0.037 & 18.832 & 0.988 & 0.122 & 1.555 & 0.983 \\
\hline $\mathrm{Pb}$ & 0.001 & -20.202 & 0.496 & 240.602 & 0.314 & 0.985 \\
\hline $\mathrm{Cr}$ & 1.172 & 0.721 & 0.476 & 1.903 & 0.555 & 0.998 \\
\hline
\end{tabular}

$\mathrm{q}_{\mathrm{m}}$ - maximum adsorption capacity; $\mathrm{b}$ or $\mathrm{K}_{\mathrm{L}}$ - adsorbent-adsorbate interaction; $\mathrm{K}_{\mathrm{f}}$ - adsorption capacity; $n$ - heterogeneity of the solid; $R^{2}$ - coefficient of determination

significant reduction in the initial concentration of metals in contact with $300 \mathrm{mg}$ of crambe byproduct, value higher than obtained at pH 5.0, where is needed $150 \mathrm{mg}$ of the adsorbent.

The removal efficiency of metals (Table 1) was elevated significantly with the increase of the mass of the adsorbent, which can be ascribed to the increased surface area of adsorption and availability of active sites. But with the increase of the adsorbent concentrations, there was a small reduction in removal that may be caused by the formation of aggregates during the sorption as described by Ekmekyapar et al. (2006).

For the construction of the isotherms, the best results obtained in the prior tests were used, with $300 \mathrm{mg}$ of adsorbent and solution at $\mathrm{pH}$ 5.0. From the data of $\mathrm{C}_{\mathrm{eq}} \mathrm{e} \mathrm{Q}_{\mathrm{eq}}$, the isotherms were built and the Figure 2 demonstrate it for each metal.

The linearizations of the isotherms were made for the mathematical models of Langmuir and Freundlich, using respective equations ( 3 and 4 ), showed previously.

The Table 2, show the obtained parameters and its respective coefficient of determination $\left(\mathrm{R}^{2}\right)$ for the linear adjustment for the studied isotherms.

The experimental data of adsorption of $\mathrm{Pb}$ and $\mathrm{Cr}$ by the crambe byproduct were better described by the Freundlich model, as this model presented higher values of $\mathrm{R}^{2}$ when compared with those obtained by Langmuir (Table 2). This fact suggests that the adsorption process is influenced by the heterogeneity of the adsorbent surface, in other words, there is more than one type of adsorption site interacting with these metals, indicating that the adsorption occurred at multilayers (Tarley \& Arruda, 2003). However, for Cd, despite the proximity of $\mathrm{R}^{2}$ values, the adsorption data presented better adjustment by the Langmuir model, indicating that the adsorption process of this metal by the crambe byproduct occurs at monolayer.

Analyzing the obtained parameters in the linearization of the Langmuir model, it was verified that the $\mathrm{Cr}$ has higher adsorption capacity $\left(\mathrm{q}_{\mathrm{m}}\right)$ than $\mathrm{Cd}$ and $\mathrm{Pb}$. However, when compared to the parameter $\mathrm{b}$ or $\mathrm{K}_{\mathrm{L}}$, the $\mathrm{Cd}$ had higher binding energy with the biosorbent.

The values of Freundlich constants $\left(\mathrm{K}_{f}\right)$ for the metals $\mathrm{Cd}$, $\mathrm{Pb}$ and $\mathrm{Cr}$ ranged from 0.122 to $240.602\left(\mathrm{mg} \mathrm{g}^{-1}\right)$ and presented the following order: $\mathrm{Pb}>\mathrm{Cr}>\mathrm{Cd}$. The constant $\mathrm{K}_{f}$ is associated with the interaction of the adsorbent with the characteristics of these metals, thus the obtained values indicate higher interaction of the crambe byproduct with the $\mathrm{Pb}$, followed by $\mathrm{Cr}$ and $\mathrm{Cd}$.

The factors favoring the adsorption of a metal species over the other have been primarily related to the electronegativity, the hydrolysis constant and ionic radius (Mimura et al., 2010). 

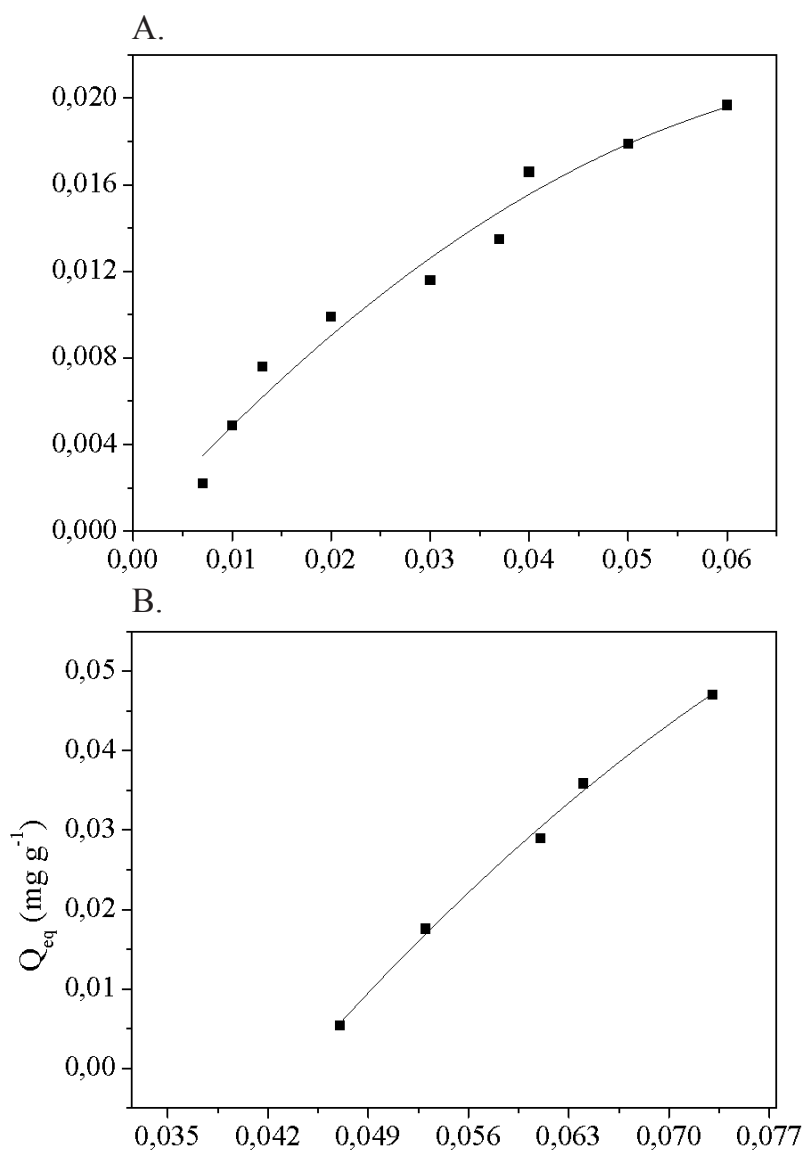

C.

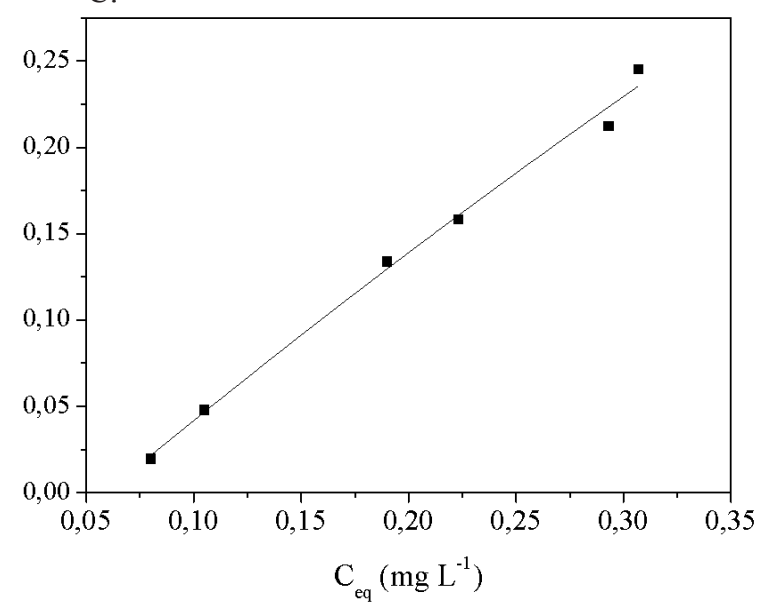

Figure 2. Adsorption isotherm for $\mathrm{Cd}(\mathrm{A}), \mathrm{Pb}(\mathrm{B})$ and $\mathrm{Cr}(\mathrm{C})$ on the crambe byproduct

Regarding the electronegativity, the selectivity order is $\mathrm{Pb}$ $>\mathrm{Cr}>\mathrm{Cd}$, since higher the electronegativity, greater is the sorption affinity (Sag et al., 2002). In relation to ionic radius, the $\mathrm{Pb}$ again would be more adsorbed, followed by $\mathrm{Cd}$ and $\mathrm{Cr}$, because the $\mathrm{Pb}$ ion has smaller radius, and can more easily penetrate into the pores and have greater access to the surface of the adsorbent.

However, it was observed that the $\mathrm{Cr}$ ion was adsorbed preferentially over the other metal species, as the mean removal percentage was $71.2 \%$ for $\mathrm{Cd}, 65 \%$ for $\mathrm{Pb}$ and $76.6 \%$ for $\mathrm{Cr}$, which can be associated to its higher positive charge and its ease to form hydrolyzed form.
The tendency to suffer hydrolysis has been observed as the most important factor in the adsorption processes, involving simultaneously several metal ions (Bayramoglu \& Arica, 2009). The Cd is the element with the lowest ability to suffer hydrolysis, followed by $\mathrm{Pb}$ and $\mathrm{Cr}$. But the results showed that the $\mathrm{Cd}$ was more adsorbed than $\mathrm{Pb}$, which can be explained by the fact that this metal has presented greater reactivity to the active sites of the adsorbent, whereas the parameter $n$ indicates the reactivity of active sites in the linearization by the Freundlich model.

Thus, examining the parameter $\mathrm{n}$ (Table 2) it can be observed that the adsorption process of the $\mathrm{Cd}$ by the adsorbent is favorable, since according to Sodré et al. (2001), when the values of $\mathrm{n}$ are above 1 , this is a strong indication of the presence of highly energetic sites, suggesting that they are the first to be occupied by the metals, resulting in a high energetic interaction and high reactivity.

Contaminated water usually, can contain more than one metal species. The adsorption capacity of one specific metal can be reduced in multi-element solutions when compared to the adsorption of this same metal in mono-element solution, and this decrease can be attributed to the lower amount of available active sites, since the binding sites are competitively divided between the metals in the solution (Sharma et al., 2007; Bueno et al., 2009). This was confirmed in a study using seeds of Moringa oleifera in the sorption of $\mathrm{Cd}, \mathrm{Cr}$ and $\mathrm{Ni}$ independently and in ternary mixtures, where the adsorption values decreased about 10 to $20 \%$ when compared to adsorption using a mono-element solution (Sharma et al., 2007).

Despite the above mentioned factors interfer in the adsorption, the concentration of the elements should also be considered, since this was different for each metal, and therefore the order of preference with respect to the adsorption selectivity, cannot be established, given that the $\mathrm{Cr}$ concentration was higher than the other metals.

\section{Conclusions}

1. The studies performed to evaluate the optimal conditions for the adsorption process showed results more efficient at $\mathrm{pH}$ 5.0.

2. From the results of linearization of the isotherms, it was concluded that the adsorption of $\mathrm{Pb}$ and $\mathrm{Cr}$ by the crambe by product were better described by the Freundlich model, while for the $\mathrm{Cd}$ adsorption the linearization had best adjustment by the Langmuir model.

3 . The obtained results demonstrated that the crambe (Crambe abyssinica Hochst) by product can be effective in the treatment of wastewater containing the toxic metals $\mathrm{Cd}$, $\mathrm{Pb}$ and $\mathrm{Cr}$, mainly by being a low cost option and a byproduct that requires no previous treatment.

\section{ACKNOWLEDGEMENTS}

The authors would like to thank the Araucaria Foundation - SETI/PR for funding, through the Research Productivity Scholarship. Thanks are also due to $\mathrm{CNPq} / \mathrm{MCTI}$ for funding through the project REPENSA. 


\section{Literature Cited}

Abia, A. A.;Asuquo, E. D. Lead (II) and nickel (II) adsorption kinetics from aqueous metal solutions using chemically modified and unmodified agricultural adsorbents. African Journal of Biotechnology, v.5, p.1475-1482, 2006.

Aguiar, M. R. M. P.; Novaes. A. C.; Guarino, A. W. S. Remoção de metais pesados de efluentes industriais por aluminos silicatos. Química Nova, v.25,p.1145-1154, 2002.

AOAC - Association of Official Agriculture Chemists. Official methods of analysis. Maryland: Arlington 2005. 2p.

Bayramoglu, G.; Arica, M. Y. Construction a hybrid biosorbent using Scenedesmus quadricauda and Ca-alginate for biosorption of $\mathrm{Cu}(\mathrm{II}), \mathrm{Zn}(\mathrm{II})$ and $\mathrm{Ni}(\mathrm{II})$ : Kinetics and equilibrium studies. Bioresource Technology, v.100, p.186193, 2009.

Bayramoglu G.; Arica, M. Y. Preparation of a composite biosorbent using scenedesmusquadricauda biomass and alginate/polyvinyl alcohol for removal of $\mathrm{Cu}(\mathrm{II})$ and $\mathrm{Cd}(\mathrm{II})$ Ions: Isotherms, kinetics, and thermodynamic studies. Water, Air, Soiland Pollut, v.221, p.391-396, 2011.

Brasil. Ministério da Saúde. Secretaria de Vigilância em Saúde. Portaria $\mathrm{n}^{\circ} 518$, de 25 de março de 2004. Série E - Legislação de Saúde. Brasília: Ministério da Saúde, 2005. 28p.

Brasil. Conselho Nacional do Meio Ambiente CONAMA. Resolução n.357, de 17 de Março de 2005. Diário Oficial, 18 Mar. 2005. Seção 1, p58-63.

Bueno, B. M.; Molina, F. F.; Torem, M. L.;Mesquista, L. M. $\mathrm{S}$; Pino, G. A. H. Remoção de $\mathrm{Pb}(\mathrm{II})$ de soluções aquosas por biossorção em R.opacus. Escola de Minas, v.62, p.487494, 2009.

Demirbas, A. Heavy metals adsorption onto agro-based waste materials: A review, Journal of Hazardus Materials, v.157, p.220-229, 2008.

Ekmekyapar, F.; Aslan, A.; Bayhan, Y. K.;Cakici, A. Biosorption of copper (II) by non-living lichen biomass of Cladoniarangiformis Hoffm. Journal Hazardous Materials, v.137, p.293-298, 2006.

Gonçalves Jr. A. C.; Luchese, E. B.; Lenzi, E. Avaliação da fitodisponibilidade de cádmio, chumbo e cromo, em soja cultivada em Latossolo Vermelho escuro tratado com fertilizantes comerciais. Química Nova, v.23, p.173-177, 2000.

Gonçalves Jr.; A. C.; Nacke, H.; Schwantes, D.; Nava, I. N.; Strey, L. Phytoavailability of toxic heavy metals and productivity in wheat cultivated under residual effect of fertilization in soybean culture. Water, Air and Soil Pollution, v.220, p.205-211, 2011.

Gonçalves Jr., A. C.; Pessoa, A. C. S. Fitodisponibilidade de cádmio, chumbo e cromo, em soja cultivada em Argissolo Vermelho eutroférrico a partir de adubos comerciais. Scientia Agraria, v.3, p.19-23, 2002.

Gonçalves Jr, A. C.; Selzlein, C.; Nacke, H. Uso de biomassa seca de aguapé (Eichorniacrassipes) visando à remoção de metais pesados tóxicos de soluções contaminadas. Acta Scientiarum Technology, v.31, p.103-108, 2009.
IUPAC - International Union Pure and Applied Chemistry. Standard methods for the analysis of oils, fats and derivatives: Method 1121. In: Paquot, C.; Haufenne, A. (ed.) Determination of moisture and volatiles matter content. Oxford: Blackwell, 1988. p.13-16.

Kabata-Pendias, A.; Pendias, H. Trace elements in soils and plants. Boca Raton: CRC Press, 1987. 315p.

Mimura, A. M. S.; Vieira, T. V. A.; Martelli, P. B.; Gorgulho, H. F. Aplicação da casca de arroz na adsorção dos íons $\mathrm{Cu}^{2+}$, $\mathrm{Al}^{3+}, \mathrm{Ni}^{2+}$ e Zn ${ }^{2+}$. Química Nova, v.33, p.1279-1284, 2010.

Oliveira L. S.; Franca, A. S.; Oliveira, V. F.; Salles, A. Use of Crambea byssinica press cake as a biosorbent for waste water treatment. In: International Conference on Chemical, Biological \& Environmental Engineering, 2009, Singapure. Proceedings... Londres: Glamorgan University, 2009. p.25-28.

Pitol, C.; Broch, D. L.; Roscoe, R. Tecnologia e produção: Crambe. Maracajú: Fundação MS, 2010. 60p.

Reedy, D. H. K.; Seshaiah, K.; Reddy, A.V. R.; Rao, M. M.; Wang, M. C. Biosorption of $\mathrm{Pb}^{2+}$ from aqueous solutions by Moringaoleifera bark: Equilibrium and kinetic studies. Journal of Hazardous Materials, v.174, p 831-838, 2010.

Sag, Y., Akeael, B.; Kutsal, T. Ternerybiosorptionequilibria of $\mathrm{Cr}$ (VI), Cu (II) and Cd (II), on Rhizopusarrihzus. Separation Science and Technology, v.37, p.279-309, 2002.

Salehizadeh, H.;Shojaosadati, S.A. Removal of metal ions from aqueous solution by polysaccharide produced from Bacillus firmus. Water Research, v.37, p.4231-4235, 2003.

Santos, V. C. G. dos; Souza, J. V. T. M. de; Tarley, C. R. T.; Caetano, J.; Dragunski, D. C. Copper ions adsorption from aqueous médium using the biosorbent sugarcane bagasse in naturaand chemically modified. Water, Air, Soil Pollution, v.216, p.351-359, 2010.

Sharma, P.; Kumari, P.; Srivastava, M. M.; Srivastava S. Ternary biosorption studies of $\mathrm{Cd}(\mathrm{II}), \mathrm{Cr}(\mathrm{II})$ and $\mathrm{Ni}$ (II) on shelled Moringaoleifera seeds. Bioresource Technology, v.98, p.474-477, 2007.

Sodré, F. F.; Lenzi, E.; Costa, A. C. Utilização de modelos físico-químicos de adsorção no estudo do Comportamento do cobre em solos argilosos. Química Nova,v.24, p.324330, 2001.

Sousa, F. W.; Moreira, S. A.; Oliveira, A. G.; Cavalcante, R. M.; Nascimento, R. F.; Rosa, M. F. The use ofgreencoconutshells as absorbents in thetoxicmetals. Química Nova, v.30, p.1153-1157, 2007.

Souza, A. D. V.; Fávaro, S. P.; Ítavo, L. C. V.; Roscoe, R. Caracterização química de sementes e tortas de pinhão manso, nabo forrageiro e crambe. Pesquisa Agropecuária Brasileira, v.44, p.1328-1335, 2009.

Sud, D.; Mahajan, G.; Kaur, M. P. Agriculturalwaste material as potentialadsorbent for sequestering heavy metal ionsfromaqueoussolutions - A review. Bioresource Technology, v.99, p.6017-6027, 2008.

Tarley, C. R. T.; Arruda, M. A. Z. Adsorventes naturais: potencialidades e aplicações da esponja natural (Luffacylindrica) na remoção de chumbo em efluentes de laboratório. Analytica, v.4, p.25-31, 2003.

Welz, B.; Sperling, M. Atomic absorption spectrometry, 2.ed., Weinheim: Wiley-VCH, 1999.941p. 